\title{
INNOVATIVE WORK BEHAVIOUR: AN INTEGRATIVE INVESTIGATION OF PERSON-JOB FIT, PERSON-ORGANIZATION FIT, AND PERSON-GROUP FIT
}

\author{
Emiliana Sri PUDJIARTI*, Prihatin Tiyanto Priagung HUTOMO
}

Universitas 17 Agustus 1945 Semarang, Indonesia

Received 13 March 2019; accepted 22 July 2019

\begin{abstract}
In relation to the problem of SME productivity, it is necessary to investigate whether there is a problem of mismatch between workers and work and groups and corporate cultural values. This study aims to analyze whether the concept of innovative work behavior can mediate the relationship of person-job fit, person-organization fit and person-group fit to job performance. The study was conducted in the metal SME industry in Tegal Regency, with 256 respondents. Data collection tools use questionnaires and interviews. Data analysis is done with a structural equation model. Based on the results of the analysis, there is a positive relationship between variables. This illustrates that the challenges of SMEs in the future are to maintain the best human resources to remain committed to the organization. In maintaining its existence, alignment of individual values with work, organization and groups is the best tool to achieve goals through innovative changes in employee behavior, and also to lay a solid foundation in the recruitment and selection process of new employees that have the potential to increase job performance.
\end{abstract}

Keywords: HR development, employee engagement, person-fit-organization, competitiveness.

JEL Classification: M52, M54.

\section{Introduction}

Employee performance in the SME sector tends to be low because of the lack of appropriate skills and in accordance with the needs of the work (Saleh and Ndubisi 2006). This is likely to affect the ability of employees to provide the standards of job performance expected by the company (Aris 2007, Napitupulu et al. 2017). This condition is a challenge faced by SMEs related to the recruitment and selection process in order to find the harmony of individual work with work. Bowen et al. (1991) stated that in recruitment and selection practices, one must pay attention to the suitability between knowledge, skills and abilities that are fit with certain job requirements, but also must fit between personal characteristics and organizational culture, which is more often referred to as a person-organization fit, because good and appropriate work will provide assurance of the effectiveness of the completion of the work (Tims et al. 2016).

The results of previous studies on the relationship between work suitability and work performance of personnel still found mixed results. In a separate study, personjob fit is found to be closely related to productivity and commitment and work performance (Afsar et al. 2015) and has a positive effect on performance, job satisfaction, and reduced work pressure, motivation. However (KristofBrown et al. 2005) found that the suitability of people with work and with the organizational environment was proven to increase job performance, even though the correlation had a weak tendency. These findings contradict the findings (Kristof-Brown et al. 2002), where job-person fit is found to correlate very highly with work performance. Although these studies prove that person-job fit can affect work performance, the number of studies is still limited (Mosley 2003), so further investigation is needed to further explore the relationships that may exist between person-job fit and job performance. Innovative performance is measured by the success of organizational members creating solutions to problems, and finding new approaches in the implementation of tasks, and they are enthusiastic about innovative ideas, all of which systematically introduce innovative ideas into work practices and are proactive in the development of new tasks related to tasks that developed (De Jong and Den Hartog 2010, Pudjiarti 2018).

${ }^{*}$ Corresponding author. E-mail: emilpujiarti@gmail.com 
Someone feels working in accordance with his or her passion, happy in working on tasks that are his or her responsibility, familiarity and harmonization of relationships between employees at all levels. The atmosphere of a comfortable work environment in exploring brilliant ideas in creating new work practices enhances innovative behavior. The results of this study are the same as the studies conducted (Afsar et al. 2015). Innovative work behavior is a multidimensional of superior performance methods, in which there are dimensions of generation ideas namely, introducing creative ideas, promotional ideas, and always trying to get support for the implementation of ideas that have been put forward (Krause 2004). Innovative work behavior produces work commitments, namely an attitude that shows self motivation and personal commitment to innovative ideas and there is a desire and action to implement these ideas into real work practices with renewal. Workers who work in metal SMEs in Tegal Regency. Based on data from the Industry and Labor Office of Tegal Regency in 2017, the number of metal SMEs in Tegal Regency was 2,929 business units, and of these, 93\% or 2,681 business units were regional economic drivers, and $7 \%$ or 248 business units were supporting industries. The metal industry absorbs 30,933 people. This study aims to provide further understandings about the effect of job performance at the group or team level as well as at the organizational level, and how appropriate each other at the team and organization level. Secondly, this study explores the dynamics of perceptions of person job fit and person organization fit as well as person-fit groups with innovative behavior. Finally, this study investigates the role of innovative behavior as a mediation process about how it relates to job performance.

\section{Literature review and hypotheses}

\subsection{Person-job fit and person-organization fit on innovative behavior}

Person-job fit focuses on individual-level analysis and ensures that employees have the technical expertise to do the work assigned to them and contribute to added value (Afsar et al. 2015). While the emphasis on person-organization fit lies in the suitability of the personality, needs, and value of employees with the values and context in the organization (Afsar et al. 2015). Tims et al. (2016) explains that employees will be more likely to better understand the job well if there is a need for conformity of personal values with work values. In the context of such relationships, work is not merely seen as a hierarchical relationship, but rather is designed as an opportunity to produce activities that are personally meaningful through interaction with others. The suitability of the value of work with employee personal identity will further enable the work to be more innovative and apply it to their work (Afsar et al. 2015).

Person-organization fit is also proposed to be an important antecedent of behavioral outcomes. It is assumed that an organization that has a high person-organization fit will lead to extra-role behavior that is more often done by employees. Extras can enhance individual initiatives and these initiatives instill innovative behavior among employees (Afsar et al. 2015). Moreover, Afsar et al. (2015) also found that employees' perceptions of organization and similar values to organizational values predict strong innovative work behavior in proportion to their suitability with job characteristics.

$H 1=$ There is an effect of person-groups fit on innovative work behavior

$\mathrm{H} 2$ = There is an influence of person-organization fit on innovative work behavior

\subsection{Effect of person-groups fit on innovative work behavior}

A team is defined as a work arrangement in which individuals work interdependently to achieve goals that are collectively responsible for the results of work, where a group and individuals are seen as whole social identities (Cohen and Bailey 1997). This condition makes it easier for team members to utilize their knowledge and increase the creation of new knowledge (Reagans et al. 2005). Furthermore, teamwork can also benefit individual creativity, because individuals tend to experience positive feelings through working together on teams (Richter et al. 2011).

Furthermore, the use of cooperation in a wider team tends to be associated with a broader organizational structure, because teamwork is related to changes in reporting relationships, if the ideas in the team are good, then attention will be paid to the main decision makers to get approval in resource utilization power, or so that the decision to adopt the new idea can be made at the appropriate organizational level (Zaltman and Duncan 1975). Attractiveness among people in a group, because of the similarity of attitudes and experiences, this can strengthen communication between group members (Pudjiarti and Suharnomo 2018), and if group members have the same attitude regarding work execution, it is possible to collaborate. If not, conflict will occur (Molleman and Slomp 2006).

H3 $=$ There is an effect of person-groups fit on innovative work behavior

\subsection{Effect of fit person-groups on job performance}

Working groups are an important component in achieving organizational effectiveness, because group success is very important for the organization's function, continuation, growth, and success. The effectiveness of groups in the organization will be better predicted which groups are the most suitable to face the challenges and opportunities faced by the organization. Research on person-groups fit is focused on individuals, for example satisfaction and individual performance (Kristof-Brown et al. 2005), subjective, or perceptual fit, and objective fit (Young Seong and Kristof-Brown 2012). The findings from (Kozlowski and Bell 2003) conclude that group development has an 
important impact on group experience, both objectively and subjectively.

Many mechanisms that underlie the influence of person-groups fit on performance and other work outcomes with one of the possible processes in this relationship is communication, a key process that contributes to group effectiveness (Mesmer-Magnus and DeChurch 2009). Research on group communication patterns mainly investigates how groups communicate when important information is distributed equally, because groups consist of individuals who are attuned and aligned, without dominance and demographic differences. (Phillips et al. 2004) conclude that communication patterns in groups can influence group performance. The suitability of these person-groups can act as input in the communication process because of their relationship with high-level characteristics (Kristof-Brown et al. 2005).

$\mathrm{H} 4=$ There is an effect of person-groups fit on innovative work behavior

\subsection{Person-job fit and person-organization fit on job performance}

Person-Job fit can be a predictor of job performance, because individuals with high person-job-fit are proven to have high work results (Icheme et al. 2017). Furthermore, congruence theory explains that individuals with suitable work between individual preferences and job requirements, skills and knowledge abilities (KSA) are able to produce high motivation (Icheme et al. 2017, Anggraeni 2018), and this condition is very important for improved job performance. Caldwell and O'Reilly III (1990) examined the relationship between Person-Job Fit and objective performance and found that the effect size was smaller than that found when checking performance. Person-Job Fit occurs when individuals and organizations meet shared needs and share the fundamental characteristics of this type of match are found to be associated with individual and organizational pre-recruitment processes (Judge and Cable 1997).

Chatman (1989) defines person organization fit as the suitability of company norms and values with employee values. The results of the study (Alajmi et al. 2016) prove that person organization fit is able to improve the effectiveness of human resource management practices and competitive advantage as a mediator, these results

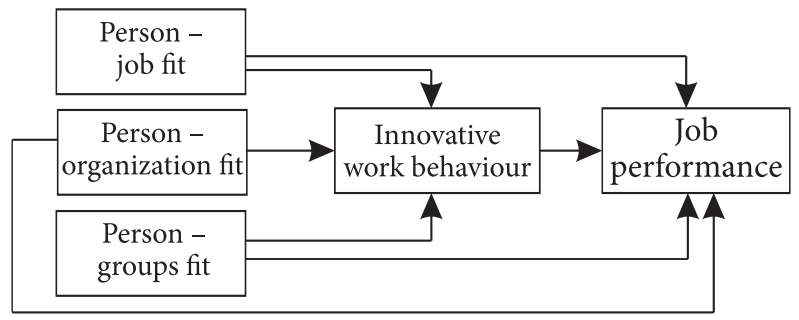

Figure 1. Framework model illustrate the importance of compatibility between individual and organizational values in the creation of positive work trends. Organizations that match the value of their employees can increase job performance, as Barbera et al. (2009) explain that individuals with a high degree of person organization fit provide new ideas and company development. Autry and Daugherty (2003) describe the suitability and harmony between organizations and individuals who are members of an organization associating a person's personality, goals, and values with the organization.

H5 = There is influence of person-group fit on job performance

H6 $=$ There is influence of person-organization fit on job performance

\subsection{Effect of innovative work behavior on job performance}

Employees' innovative work behavior is used to carry out proactive behavior in the form of personal initiatives and new ideas that are directly related to effective performance in the organization, this has been found by many researchers such as (Naranjo-Valencia et al. 2011). Evidence shows that employees' creative ideas are able to improve the work of supervisors (Oldham and Cummings 1996). Novel ideas on innovations in the form of new products, services, or proposing improvements in existing procedures and processes as well as findings on alternative solutions that are efficient and effective to implement (Zhou and Shalley 2003). Innovative ideas allow employees to improve personal work performance (Shalley et al. 2004).

H7 $=$ There is an influence of innovative work behavior on job performance

\subsection{Theoretical framework}

Based on the description in the framework of the relationship between variables as described above, then Figure 1 below is a model of the framework in building a hypothesis.

\section{Methodology}

\subsection{Research design}

This study uses survey methods to collect data from employees who currently work in metal SMEs in Tegal Regency. According to Garikai (2011), the criteria for SMEs are measured by the number of workers, capital and sales turnover. The size used is sometimes different due to differences in sectors, market area and competitors. This study uses the criteria of SMEs based on the SME Department of the World Bank, namely: the number of employees is less than 30 people; a year income does not exceed \$3 million, and total assets do not exceed \$3 million (Meghana et al. 2007, p. 4). 


\subsection{Sampling}

The population in this study were all companies belonging to the Small Metal Industry in Tegal Regency, totaling 715 businesses leading sectors of automotive component manufacturing products, both two-wheeled and more in the Districts of Talang, Adiwerna, Kramat, Tarub, Lebaksiu, and Slawi. The sample used in this study is 256 small-scale metal industry businesses, with the reason of assuming sample adequacy in structural equation models (Kline 2015). The number of samples 256 was calculated by Slovin formula:

$$
\begin{aligned}
& n=N /\left(1+N e^{2}\right) ; \\
& n=715 /(1+0.052)=256,
\end{aligned}
$$

in which $n=$ number of samples, $N=$ Total population and $e=$ error tolerance. The sampling technique was simple random sampling with the criteria of small metal businesses in the job order production system and had run a business for at least 5 years. In the area of sampling, small metal businesses located in the Districts of Talang, Adiwerna and Kramat were taken into consideration with the small-scale metal business mostly in these three regions.

\subsection{Measurement}

Person-job fit is adopted from (Cable and DeRue 2002) with 7 items, namely: the similarity of workers' expectations with what is offered by the job, the suitability of the salary offered by the work with the needs of the worker, the suitability of the training of the company with the needs of the worker, the suitability of the job when This is with the wishes / needs of the workers, the suitability of the company's needs and the expertise of the workers, the suitability of the workers' abilities with the training carried out in accordance with the needs of the work. The measurement for innovative work behavior was adopted from (Lauver and Kristof-Brown 2001) with 5 items, namely getting a higher-paying job, having enthusiasm at work, always trying to do the best at work, having satisfaction in doing work, completing routine tasks with good. The variable of Person-organization fit is adopted from (Sekiguchi 2004); with 4 items, namely value congruence; goal congruence; employee need fulfillment, culture personality congruence. The measurement for the variable of Fit groups were adopted from (Cable and DeRue 2002), with 5 items, namely: individual attractiveness in social groups, individual attractiveness in task groups, social group integration, integration of task groups, high commitment. The variable of innovative behavior was adopted from (De Jong and Den Hartog 2010) with 4 items, namely opportunity exploration, idea generation, championing, application. Job performance is adopted from (Mathis and Jackson 2011) with 4 items, namely the quality of performance given by workers is in accordance with the standards, workers have provided good work productivity, work results are better when compared to colleagues of the same level, and Work results better compared to jobs that have equal weight.

\subsection{Data analysis}

Each variable was measured using an instrument developed with a 7-point Likert scale for all measurements ranging from (1) - strongly disagree up to (7) - strongly agree. The data analysis is done by structural equation modeling (SEM) through AMOS software version 22.

\section{Results}

\subsection{Reliability and validity}

Standardized loading estimates with values $>0.7$ indicate high convergent validity (Hair et al. 2010). Convergent validity was also assessed by ave analysis showing adequate convergent validity because $>0.5$ (Hair et al. 2010). while the instrument reliability is .877 for person-job fit, .816 for person-fit, .836 for group person fit, .812 for innovative work behavior, and .803 for jiob performance. The reliability test is for all Cronbach alpha values $>.7$, so it can be concluded that the test instrument is reliable (Hair et al. 2010). Furthermore, the component analysis to test the suitability of the data with the factor analysis stated to be adequate was assessed through the KMO (Kaiser Meyer-Olkin) test, all expressed significantly with $\mathrm{p}<.05$ (Table 1).

\subsection{Descriptive statistics}

Most of the respondents were men (92.97\%), and were in a productive age, with formal education mostly high school (60.94\%) and the experience was 26 to 30 years $(24.61 \%)$. The most marketing area is outside Java (37.89\%), with the highest number of employees being 7 to 10 people (42.19\%) (Table 2).

Table 3 shows the descriptive statistics and correlations between PJ-Fit - PO-Fit - PG-Fit - IWB and Job Performance are shown in Table 3. The results showed that Innovative Work Behaviour was positively related to PJ-Fit $(\mathrm{r}=.298, \mathrm{p}<.005)$; PO-Fit $(\mathrm{r}=.205, \mathrm{p}<.005)$; PG-Fit $(\mathrm{r}=$ $.228, \mathrm{p}<.005)$. Job performance was positively related to PJ-Fit $(\mathrm{r}=.275, \mathrm{p}<.005)$; PO-Fit $(\mathrm{r}=.212$, $\mathrm{p}<.005)$; PGFit $(\mathrm{r}=.332, \mathrm{p}<.005)$; IWB $(\mathrm{r}=.357, \mathrm{p}<.005)$. The test results show that exogenous variables are significantly correlated with endogenous variables. The mean value above 5 explains that the respondent gives a high perception of all latent constructs, and the standard deviation greater than zero illustrates that the respondent's answers vary.

\subsection{Goodness of fit testing}

Testing structural equation models using AMOS V.24.00 shows the results of Chi-Square $(274,544<279,40)$; Probability $(0.0745>0.05)$; GFI / Goodness of Fit In$\operatorname{dex}=0.920 \geq 0.90$; AGFI / Adjusted Goodness of Fit Index $0.901 \geq 0.90$; RMR / Root Mean Square Residual 
Table 1. Results of reliability and validity analysis of research

\begin{tabular}{|c|c|c|c|c|c|}
\hline Construct & Indicators & Loading Factor & $\begin{array}{c}\text { KMO and } \\
\text { Bartlett's Test }\end{array}$ & Reliability & AVE \\
\hline \multirow{8}{*}{ Person-job fit } & The worker's expectations fit & $.723^{* *}$ & \multirow{8}{*}{$730.240^{* *}$} & \multirow{8}{*}{.877} & \multirow{8}{*}{.590} \\
\hline & The salary's offer-compatibility & $.724^{* *}$ & & & \\
\hline & The worker's trainning-suitability & $.699^{* *}$ & & & \\
\hline & The current's job-suitability & $.698^{* *}$ & & & \\
\hline & The worker's expertise conformity & $.711^{* *}$ & & & \\
\hline & The worker's ability-suitability & $.735^{* *}$ & & & \\
\hline & The worker's educational-conformity & $.685^{* *}$ & & & \\
\hline & The worker's expectations fit & $.723^{* *}$ & & & \\
\hline \multirow{4}{*}{$\begin{array}{l}\text { Person- } \\
\text { organization fit }\end{array}$} & Value congruence & $.746^{* *}$ & \multirow{4}{*}{$350.893^{* *}$} & \multirow{4}{*}{.816} & \multirow{4}{*}{605} \\
\hline & Goal congruence & $.662^{* *}$ & & & \\
\hline & Employee need fulfillment & $.765^{* *}$ & & & \\
\hline & Culture personality congruence & $.726^{* *}$ & & & \\
\hline \multirow{5}{*}{ Group Person fit } & $\begin{array}{l}\text { The attractiveness of individuals in social } \\
\text { groups, }\end{array}$ & $.711^{* *}$ & \multirow{5}{*}{$549.707^{* *}$} & \multirow{5}{*}{.836} & \multirow{5}{*}{.589} \\
\hline & $\begin{array}{l}\text { The attractiveness of individuals in the task } \\
\text { group, }\end{array}$ & $.673^{* *}$ & & & \\
\hline & Integration of social groups, & $.785^{* *}$ & & & \\
\hline & Integration of task groups, & $.659^{* *}$ & & & \\
\hline & High commitment. & $.719^{* *}$ & & & \\
\hline \multirow{4}{*}{$\begin{array}{l}\text { Innovative Work } \\
\text { Behaviour }\end{array}$} & Opportunity exploration, & $.671^{* *}$ & \multirow{4}{*}{$306.712^{* *}$} & \multirow{4}{*}{.812} & \multirow{4}{*}{.600} \\
\hline & generation Idea, & $.785^{* *}$ & & & \\
\hline & Championing Idea & $.673^{* *}$ & & & \\
\hline & Application Idea & $.750^{* *}$ & & & \\
\hline \multirow{4}{*}{ Job performance } & Quality of work in accordance with standards, & $.701^{* *}$ & \multirow{4}{*}{$337.208^{* *}$} & \multirow{4}{*}{.803} & \multirow{4}{*}{.589} \\
\hline & Work productivity according to standards, & $.712^{* *}$ & & & \\
\hline & $\begin{array}{l}\text { Work results are better compared to co- } \\
\text { workers who are level, }\end{array}$ & $.710^{* *}$ & & & \\
\hline & $\begin{array}{l}\text { Work is better when compared to other jobs } \\
\text { that have the same weight }\end{array}$ & $.719^{* *}$ & & & \\
\hline
\end{tabular}

Note: ${ }^{\star} \mathrm{p}<.05 ;{ }^{* *} \mathrm{p}<.001$.

Table 2. Descriptive information about participants

\begin{tabular}{|l|l|c|c|}
\hline $\begin{array}{c}\text { Characteristics of } \\
\text { Respondents }\end{array}$ & \multicolumn{1}{|c|}{ Classification } & Amount & $\%$ \\
\hline \multirow{4}{*}{ Gender } & Woman & 18 & $7.03 \%$ \\
\cline { 2 - 4 } & Man & 238 & $92.97 \%$ \\
\hline \multirow{5}{*}{ Age } & $20-29$ & 32 & $12.50 \%$ \\
\cline { 2 - 4 } & $30-39$ & 74 & $28.91 \%$ \\
\cline { 2 - 4 } & $40-49$ & 102 & $39.84 \%$ \\
\cline { 2 - 4 } & $50-59$ & 37 & $14.45 \%$ \\
\cline { 2 - 4 } & $>60$ & 11 & $4.30 \%$ \\
\hline \multirow{5}{*}{ Education } & Junior high school & 32 & $12.50 \%$ \\
\cline { 2 - 4 } & Senior high school & 156 & $60.94 \%$ \\
\cline { 2 - 4 } & Diploma & 54 & $21.09 \%$ \\
\cline { 2 - 4 } & Undergraduate & 14 & $5.47 \%$ \\
\hline \multirow{2}{*}{ Experience } & $0-5$ & 3 & $1.17 \%$ \\
\cline { 2 - 4 } & $6-10$ & 6 & $2.34 \%$ \\
\hline
\end{tabular}

\begin{tabular}{|c|c|c|c|}
\hline $\begin{array}{l}\text { Characteristics of } \\
\text { Respondents }\end{array}$ & Classification & Amount & $\%$ \\
\hline & $11-15$ & 16 & $6.25 \%$ \\
\hline & $16-20$ & 29 & $11.33 \%$ \\
\hline & $21-25$ & 43 & $16.80 \%$ \\
\hline & $26-30$ & 63 & $24.61 \%$ \\
\hline & $31-35$ & 63 & $24.61 \%$ \\
\hline & $>35$ & 33 & $12.89 \%$ \\
\hline \multirow{4}{*}{ Marketing Area } & Central Java & 43 & $16.80 \%$ \\
\hline & Java & 73 & $28.52 \%$ \\
\hline & Outside Java & 97 & $37.89 \%$ \\
\hline & Overseas & 43 & $16.80 \%$ \\
\hline \multirow{4}{*}{$\begin{array}{l}\text { Number of } \\
\text { employees }\end{array}$} & $0-3$ & 29 & $11.33 \%$ \\
\hline & $4-6$ & 56 & $21.88 \%$ \\
\hline & $7-10$ & 108 & $42.19 \%$ \\
\hline & $>10$ & 63 & $24.61 \%$ \\
\hline
\end{tabular}


Table 3. Descriptive statistics and correlations

\begin{tabular}{|c|c|c|c|c|c|c|c|c|}
\hline No & Contruct & M & SD & PJ-Fit & PO-Fit & PG-Fit & IWB & $J P$ \\
\hline 1 & Person-job fit (PJ-Fit) & 5.621 & .684 & 1 & & & & \\
\hline 2 & Person-organization fit (PO-Fit) & 5.514 & .853 & $.158^{*}$ & 1 & & & \\
\hline 3 & Group Person fit (PG-Fit) & 5.750 & .797 & $.221^{* *}$ & $.129^{*}$ & 1 & & \\
\hline 4 & Innovative Work Behaviour (IWB) & 5.790 & .750 & $.298^{* *}$ & $.205^{* *}$ & $.228^{* *}$ & 1 & \\
\hline 5 & Job performance (JP) & 5.630 & .787 & $.275^{* *}$ & $.212^{* *}$ & $.332^{* *}$ & $.357^{\star *}$ & 1 \\
\hline
\end{tabular}

Note: ${ }^{\star} \mathrm{p}<.05 ;{ }^{* *} \mathrm{p}<.001 ; \mathrm{M}=$ meanl $\mathrm{SD}=$ Standart Deviation.

$0.023<0.1$; NFI / Normal Fit Index $0.891<0.90$ (Marginal); IFI / Incremental Fit Index $0.986 \geq 0.90$; CFI / Comparative Fit Index $0.985 \geq 0.95$; Cmin / DF 1,134 $\leq 2,00$ and RMSEA $0,023 \leq 0,08$. So it can be concluded that the resulting path model is declared fit because it is in the range of cut of value required. Furthermore, a variance extract extract and reliabilty are also carried out. The results of the analysis produce coefficients for all variables above the expected cut of value of 0.7 and 0.5 .

\subsection{Hypothesis testing}

Based on the first hypothesis estimation parameter, between person-job fit and innovative work behavior shows significant results $\left(\mathrm{CR}=3.636 ; \mathrm{p}={ }^{* *}<0.01\right)$, with a significance level of $5 \%$, which means that the higher the personal suitability of the employee with the job. Complex work innovation requires various cognitive and affective efforts of employees to produce new ideas that are interesting and apply them in their work (Janssen et al. 2004). To achieve this, employees need to have a match with work (Afsar et al. 2015), thereby creating a higher level of innovative work behavior.

Testing the second hypothesis shows that personorganization fit has a positive influence on the innovative work behavior $(\mathrm{CR}=2.647$; $\mathrm{p}=.008<.005)$, with a significance level of $5 \%$. Therefore, the second hypothesis can be accepted, meaning that the higher the personal suitability of employees with organizational values, the higher the innovative work behavior. These results support Afsar et al. (2015) that organizational fit can be an important antecedent of extra behavior that can increase individual initiative and further instill innovative behavior. Employee recruitment that places more emphasis on the suitability of the mission and personal values with organizational values makes the organization not only provide opportunities for employees to work, but also to encourage them to commit to the organization, perform well and be satisfied in their work (Tsai and Yen 2017). The study of Afsar et al. (2015) also explained the organization fit can enhance the behavior of knowledge sharing which is expected to be able to encourage innovative work behavior of employees (Afsar et al. 2015, Saraç et al. 2014, Wojtczuk-Turek and Turek 2016).

The third hypothesis testing shows that Person-Group fit has a positive impact on the Innovative Work Behavior $(\mathrm{CR}=2.577 ; \mathrm{p}=.010<.005)$, with a significance level of $5 \%$. Thus the third hypothesis is proven to be accepted. This means that the more effective the person-group fit, the more the innovative work behavior. Person group fit makes it easy for team members to use shared knowledge to improve new knowledge creation (Reagans et al. 2005). Besides that, it can benefit individuals, because they experience positive feelings through working together in teams (Richter et al. 2011), and in experimental studies concluded that high group cohesiveness in teams when group members have high levels of similarity, this attitude is positively correlated with job satisfaction and organizational commitment. Likewise broader team work in organizations is significant with the level of organizational innovation (Fay et al. 2015).

The fourth hypothesis test shows that the person-job fit has a positive impact on Job performance $(\mathrm{CR}=2.114$;

Table 3. Hypothesis testing results

\begin{tabular}{|l|l|l|c|c|c|c|c|}
\hline \multicolumn{2}{|c|}{} & \multicolumn{2}{|c|}{ Unstandardized } & \multirow{2}{*}{$\begin{array}{c}\text { Standardized } \\
\text { Estimate }\end{array}$} & CC.R. \\
\cline { 3 - 7 } & $\rightarrow$ & Estimate & S.E & & \\
\hline Person-job fit & $\rightarrow$ & Innovative Work Behaviour & .296 & .081 & .276 & 3.636 & $* * *$ \\
\hline Person-organization fit & $\rightarrow$ & Innovative Work Behaviour & .154 & .058 & .202 & 2.647 & .008 \\
\hline Person-Group fit & $\rightarrow$ & Innovative Work Behaviour & .194 & .075 & .194 & 2.577 & .010 \\
\hline Person-job fit & $\rightarrow$ & Job performance & .167 & .057 & .157 & 2.114 & .034 \\
\hline Person-organization fit & $\rightarrow$ & Job performance & .119 & .079 & .156 & 2.126 & .033 \\
\hline Person-Group fit & $\rightarrow$ & Job performance & .233 & .077 & .234 & 3.041 & .002 \\
\hline Innovative Behaviour & $\rightarrow$ & Job performance & .270 & .085 & .271 & 3.165 & .002 \\
\hline
\end{tabular}


$\mathrm{p}=.034<.005)$, with a significance level of $5 \%$. Thus the fourth hypothesis is proven to be accepted. This means that the higher the level of person-job fit, the impact on job performance. This study is consistent with Afsar et al. (2015), Autry and Daugherty (2003) demonstrating that personnel suitability can be a predictor of job performance. This relationship is explained by (Scroggins 2008) regarding self-concept and conformity with work, so employees tend to adjust to fit the job requirements.

The fifth hypothesis test shows that the person-organization fit variable has a positive impact on job performance $(\mathrm{CR}=2.126 ; \mathrm{p}=.033<.005)$, with a significance level of $5 \%$. Thus the fifth hypothesis is proven to be accepted. This means that the higher the degree of personorganization fit, the impact on job performance. The results of this study are in line with the findings of Afsar et al. (2015), Autry and Daugherty (2003) pointing out that alignment between employee goals and organizational goals can increase the intensity of employees in completing work. This harmony is likely to be more able to facilitate the resource exchange between the organization and employees and increase the formation of strong relationships. Employees who have high compatibility will look more passionate about work, so higher work performance and greater career opportunities will be easier to obtain (Astakhova and Porter 2015). Likewise, employees who have the value congruence with organizational values will find it easier to have a closer relationship (Astakhova and Porter 2015). Similarly, employees whose values are in accordance with the values of the organization will be easier to have a higher relationship (Alajmi et al. 2016, Sultanova and Chechina 2016).

Testing the sixth hypothesis shows that the persongroup fit variable has a positive impact on Job performance $(\mathrm{CR}=3.041 ; \mathrm{p}=.002<.005)$, with a significance level of $5 \%$. Thus the sixth hypothesis is proven to be accepted. This means that the higher the degree of person-group fit, the impact on job performance. Some studies show that similarities among group members positively influence group decisions (Vogel and Feldman 2009). Value congruence, personality traits and relational demographics cause communication with other members to increase with regard to group productivity and performance because it strengthens employee interactions. Synergy and group performance will develop (Stanley 2002), because productivity at the unit level is a function of employee collective productivity, it is influenced by norms and interactions between employees that influence the emergence of group performance (Whitman et al. 2010).

The statisctical results of seventh hypothesis shows that the Innovative Work behavior variable has a positive impact on Job performance $(\mathrm{CR}=3.165 ; \mathrm{p}=.002<.005)$, with a significance level of $5 \%$. Thus the sixth hypothesis is proven to be accepted. In a rapidly changing business environment, the survival of the organization will be largely determined by the work behavior of employees to always think and apply innovative ideas in response to changes in the business environment (Pieterse et al. 2010). In this context, organizational performance can be improved by organizations by giving more space for innovative employees to apply their creative ideas to improve the performance of products and services (De Jong and Den Hartog 2010).

\subsection{Sobel tests}

Sobel tests calculator for the significance of mediation to determine the feasibility of mediating variables. The results of the Sobel test of each variable are tested significantly, because the Sobel test value is above the required cut of value, as well as the significance value of one-tailed and two-tailed probability is smaller than 0.05 , meaning that the innovative variable work behavior influences significant to the relationship between variables person-job fit, person organization fit and person group fit to job performance. In other words, innovative work behavior variables deserve to be mediated (Table 4).

Sobel's test results prove that innovative work behavior is able to mediate the influence of Person-job fit, Person organization fit, Person group fit has been identified by researchers as important factors affecting IWB (Afsar et al. 2015, Saraç et al. 2014, Wojtczuk-Turek and Turek 2016). Furthermore IWB is also significant with performance (De Jong and Den Hartog 2010, Pieterse et al. 2010).

\section{Conclusions}

These results have several important implications for the human resource management literature. This finding shows that person-job fit, person organization fit and person group fit job are significant with innovative work behavior and job performance. In general, the concept of the suitability of individuals with work, groups and organizations is a concept focused on aspects of intangible resources, which are intangible capabilities of the organization and become factors driving job performance.

Table 4. Testing innovative work behavior mediation variable with Sobel test

\begin{tabular}{|c|l|c|c|c|c|}
\hline No & \multicolumn{1}{|c|}{ Variable } & Sobel test statistic & One-tailed probability & Two-tailed probability & Information \\
\hline 1 & Person-job fit & 2.328 & .00995 & .00199 & Eligible \\
\hline 2 & Person organization fit & 2.351 & .00934 & .00186 & Eligible \\
\hline 3 & Person group fit & 2.087 & .00222 & .04456 & Eligible \\
\hline
\end{tabular}


Hence, the organization must have a climate that allows each member of the organization to be encouraged to continue learning in making adjustments and developing potential, expanding and enriching the culture of work and making human resource development strategies, especially the recruitment and selection process as the center of work policy for the sake of occurrence sustainable transformation, and to win in global competition. Understanding of person-job fit, person-organization fit and person-fit groups can help organizations to choose employees with values and beliefs that are appropriate to the organization and form experiences that can strengthen that suitability. This statement shows that the challenge for the organization in the future is to maintain the best human resources to remain committed to the organization. In maintaining its existence, and aligning individual values with work, groups and organizations are the best tools to achieve goals, and efforts to lay the foundation for a concept of human resource development that has the potential to increase job performance.

\section{Limitations and future research agenda}

This study has limitations in its cross-sectional design which gives more emphasize the relationship between the concepts. This study conceptualization as a brief description at a certain time does not discuss the concept of worker competence which is the direction and strategy to achieve the goal. Therefore longitudinal studies in future research can assess results in the long run, so that efforts to improve the performance of SME workers can be achieved.

\section{References}

Afsar B, Badir Y, Khan MM (2015) Person-job fit, person-organization fit and innovative work behavior: The mediating role of innovation trust. The Journal of High Technology Management Research 26 (2): 105-116.

https://doi.org/10.1016/j.hitech.2015.09.001

Alajmi SA, Alenezi MA (2016) Human resource management practice and competitive advantage: the mediator role of person organization fit. Global Journal Of Human Resource Management 4 (1): 65-82.

Anggraeni AI (2018) Millennial and psychological contract: social constructivist approach. In Psychology of Retention (pp. 287-306). Springer, Cham.

https://doi.org/10.1007/978-3-319-98920-4_14

Aris NM (2007) SMEs: Building blocks for economic growth. Department of National Statistics, Malaysia.

Astakhova MN, Porter G (2015) Understanding the work passion-performance relationship: The mediating role of organizational identification and moderating role of fit at work. Human Relations 68 (8): 1315-1346.

https://doi.org/10.1177/0018726714555204

Autry CW, Daugherty PJ (2003) Warehouse operations employees: linking person-organization fit, job satisfaction, and coping responses. Journal of Business Logistics 24 (1): 171-197. https://doi.org/10.1002/j.2158-1592.2003.tb00036.x
Barbera KM, Macey WH, Martin N, Schneider B (2009) Driving customer satisfaction and financial success through employee engagement. People \& Strategy 32 (2): 22-28.

Bowen DE, Ledford Jr GE, Nathan BR (1991) Hiring for the organization, not the job. Academy of Management Perspectives 5 (4): 35-51. https://doi.org/10.5465/ame.1991.4274747

Cable DM, DeRue DS (2002) The convergent and discriminant validity of subjective fit perceptions. Journal of Applied Psychology 87 (5): 875. https://doi.org/10.1037//00219010.87.5.875

Caldwell DF, O’Reilly III CA (1990) Measuring person-job fit with a profile-comparison process. Journal of Applied Psychology 75 (6): 648. https://doi.org/10.1037/0021-9010.75.6.648

Chatman JA (1989, August) Matching people and organizations: Selection and socialization in public accounting firms. In Academy of Management proceedings (Vol. 1989, No. 1, pp. 199-203). Briarcliff Manor, NY 10510: Academy of Management. https://doi.org/10.5465/ambpp.1989.4980837

Cohen SG, Bailey DE (1997) What makes teams work: Group effectiveness research from the shop floor to the executive suite. Journal of Management 23 (3): 239-290. https://doi.org/10.1016/S0149-2063(97)90034-9

De Jong J, Den Hartog D (2010) Measuring innovative work behaviour. Creativity and Innovation Management 19 (1): 23 36. https://doi.org/10.1111/j.1467-8691.2010.00547.x

Fay D, Shipton H, West MA, Patterson M (2015) Teamwork and organizational innovation: The moderating role of the HRM context. Creativity and Innovation Management 24 (2): 261277. https://doi.org/10.1111/caim. 12100

Garikai B (2011) Growth of SMEs in developing nations: special reference to AGOA. COMESA, Lusaka. Zambia.

Hair J, Black W, Babin B, Anderson R, Tatham R (2010) Multivariate data analysis-a global perspective (global edition). Edinburgh gate.

Icheme MO, Ezenwakwelu CA, Owuze Cletus A (2017) Personnel Selection and person-organization, job-fit, implication for employees' performance in Nigeria. International Journal of Scientific Research and Management (IJSRM) 5 (11): 7361-7369.

Janssen O, Van de Vliert E, West M (2004) The bright and dark sides of individual and group innovation: A special issue introduction. Journal of Organizational Behavior 25 (2): 129145. https://doi.org/10.1002/job.242

Judge TA, Cable DM (1997) Applicant personality, organizational culture, and organization attraction. Personnel Psychology 50 (2): 359-394.

https://doi.org/10.1111/j.1744-6570.1997.tb00912.x

Kline RB (2015) Principles and practice of structural equation modeling. Guilford publications.

Kozlowski SW, Bell BS (2003) Work groups and teams in organizations. Handbook of Psychology, 333-375. https://doi.org/10.1002/0471264385.wei1214

Krause DE (2004) Influence-based leadership as a determinant of the inclination to innovate and of innovation-related behaviors: An empirical investigation. The Leadership Quarterly 15 (1): 79-102. https://doi.org/10.1016/j.leaqua.2003.12.006

Kristof-Brown AL, Jansen KJ, Colbert AE (2002) A policycapturing study of the simultaneous effects of fit with jobs, groups, and organizations. Journal of Applied Psychology 87 (5): 985. https://doi.org/10.1037/0021-9010.87.5.985

Kristof-Brown AL, Zimmerman RD, Johnson EC (2005) Consequences of individuals' fit at work: a meta-analysis of personjob, person-organization, person-group, and person-supervisor fit. Personnel Psychology 58 (2): 281-342. https://doi.org/10.1111/j.1744-6570.2005.00672.x 
Lauver KJ, Kristof-Brown A (2001) Distinguishing between employees' perceptions of person-job and person-organization fit. Journal of Vocational Behavior 59 (3): 454-470. https://doi.org/10.1006/jvbe.2001.1807

Mathis RL, Jackson JH (2011) Human resource management: Essential perspectives. Cengage Learning.

Meghana A, Beck T, Demirgüç-Kunt A (2007) Small and medium enterprises across the globe. Small Business Economics 29 (4): 415-434. https://doi.org/10.1007/s11187-006-9002-5

Mesmer-Magnus JR, DeChurch LA (2009) Information sharing and team performance: A meta-analysis. Journal of Applied Psychology 94 (2): 535. https://doi.org/10.1037/a0013773

Molleman E, Slomp J (2006) The impact of team and work characteristics on team functioning. Human Factors and Ergonomics in Manufacturing \& Service Industries 16 (1): 1-15. https://doi.org/10.1002/hfm.20041

Mosley D (2003) The influence of person-job fit, person-organization fit, and self-efficacy perceptions on work attitudes, job performance, and turnover. Doctoral dissertation. Retrieved from ProQuest Dissertations and Theses database (AAT 3043161) https://elibrary.ru/item.asp?id=5269141

Napitupulu S, Haryono T, Laksmi Riani A, Sawitri HSR, Harsono $M$ (2017) The impact of career development on employee performance: an empirical study of the public sector in Indonesia. International Review of Public Administration 22 (3): 276-299. https://doi.org/10.1080/12294659.2017.1368003

Naranjo-Valencia JC, Jiménez-Jiménez D, Sanz-Valle R (2011) Innovation or imitation? The role of organizational culture. Management Decision 49 (1): 55-72. https://doi.org/10.1108/00251741111094437

Oldham GR, Cummings A (1996) Employee creativity: personal and contextual factors at work. Academy of Management Journal 39 (3): 607-634. https://doi.org/10.5465/256657

Phillips KW, Mannix EA, Neale MA, Gruenfeld DH (2004) Diverse groups and information sharing: The effects of congruent ties. Journal of Experimental Social Psychology 40 (4): 497-510. https://doi.org/10.1016/j.jesp.2003.10.003

Pieterse AN, Van Knippenberg D, Schippers M, Stam D (2010) Transformational and transactional leadership and innovative behavior: The moderating role of psychological empowerment. Journal of Organizational Behavior 31 (4): 609-623. https://doi.org/10.1002/job.650

Pudjiarti ES (2018) Elements of entrepreneurship in private universities: Organizational change capacity, innovative capability and the performance. Journal of Entrepreneurship Education 21 (2): 1-15.

Pudjiarti ES, Suharnomo S (2018) Does Institutional intervention play a role in small business clustering? An empirical evidence from Semarang, Indonesia. Quality Access to Success 19 (163): 52-59.

Reagans R, Argote L, Brooks D (2005) Individual experience and experience working together: Predicting learning rates from knowing who knows what and knowing how to work together. Management Science 51 (6): 869-881. https://doi.org/10.1287/mnsc.1050.0366

Richter A, Dawson J, West M (2011) The effectiveness of teams in organizations: A meta-analysis. The International Journal of Human Resource Management 22 (13): 2749-2769. https://doi.org/10.1080/09585192.2011.573971
Saleh AS, Ndubisi NO (2006). SME Development in Malaysia: Domestic and Global Challenges, Department of Economics, University of Wollongong https://ro.uow.edu.au/commwkpapers/139

Saraç M, Efil I, Eryilmaz M (2014) A study of the relationship between person-organization fit and employee creativity. Management Research Review 37 (5): 479-501. https://doi.org/10.1108/MRR-01-2013-0025

Scroggins WA (2008) Antecedents and outcomes of experienced meaningful work: A person-job fit perspective. The Journal of Business Inquiry 7 (1): 68-78.

Sekiguchi T (2004) Person-organization fit and person-job fit in employee selection: A review of the literature. Osaka Keidai Ronshu 54 (6): 179-196.

Shalley CE, Zhou J, Oldham GR (2004) The effects of personal and contextual characteristics on creativity: Where should we go from here? Journal of Management 30 (6): 933-958. https://doi.org/10.1016/j.jm.2004.06.007

Stanley CL (2002) Examination of group supervision: Cohesiveness and supervisor leadership as predictors of intern performance. Seattle Pacific University. https://elibrary.ru/item.asp?id=5245131.

Sultanova V, Chechina S (2016) Human capital as a key factor of economic growth in crisis. European Research Studies Journal 19 (2): 72-79.

Tims M, Derks D, Bakker AB (2016) Job crafting and its relationships with person-job fit and meaningfulness: A three-wave study. Journal of Vocational Behavior 92: 44-53. https://doi.org/10.1016/j.jvb.2015.11.007

Tsai PC-F, Yen Y-F (2017) Study of the relationship of workplace person-environment fit, country identification and affective commitment-evidence of Chinese immigrant wives in Taiwan. Athens Journal of Business \& Economics 3 (2): 101-122. https://doi.org/10.30958/ajbe.3.2.2

Vogel RM, Feldman DC (2009) Integrating the levels of personenvironment fit: The roles of vocational fit and group fit. Journal of Vocational Behavior 75 (1): 68-81. https://doi.org/10.1016/j.jvb.2009.03.007

Whitman DS, Van Rooy DL, Viswesvaran C (2010) Satisfaction, citizenship behaviors, and performance in work units: A meta-analysis of collective construct relations. Personnel Psychology 63 (1): 41-81.

https://doi.org/10.1111/j.1744-6570.2009.01162.x

Wojtczuk-Turek A, Turek D (2016) The significance of perceived social-organization climate for creating employees' innovativeness: The mediating role of person-organization fit. Management Research Review 39 (2): 167-195. https://doi.org/10.1108/MRR-11-2015-0268

Young Seong J, Kristof-Brown AL (2012) Testing multidimensional models of person-group fit. Journal of Managerial Psychology 27 (6): 536-556. https://doi.org/10.1108/02683941211252419

Zaltman G, Duncan R (1975) J. Holbek (1973) Innovations and organizations. New York: Wiley.

Zhou J, Shalley CE (2003) Research on employee creativity: A critical review and directions for future research. Research in personnel and human resources management (pp. 165-217): Emerald Group Publishing Limited. https://doi.org/10.1016/S0742-7301(03)22004-1 